\title{
The Role Weight of Key Factors Determining the (Infrastructure and Traffic) Intensity of Aviation for the Countries of the World
}

Ferenc Erdösi MTA KRTK

E-mail: erdosi@rkk.hu

Keywords: air transportation, economy,

infrastructure, interdependence,

correlation, tourism, specific indicators,

continents, countries
The interdependence between air transport and the economic sector can be examined from two directions. Several theoretical and regional studies were published on the economic impact of aviation, which is the fastest growing but the most environmentally harmful among all of the transport subsections. However, out of the many factors that influence the development level / performance of aviation, only the thematization and examination of the relationship with the GDP per capita was carried out for a narrower group of countries.

Compared to the past, the author methodologically exceeded previous studies in many respects, since the correlation calculations were carried out on 168 countries on 8 hypothetical acting factors and other specific indicators instead of one factor. Furthermore (breaking with the earlier practice), the indicator of passenger traffic per inhabitant was produced not from the data of official statistics (such as ICAO and IATA), which is only related to airlines registered in the given country, but from the complete national airport traffic data that was painstakingly generated by the author.

In addition to the global scale, the evaluation of correlation coefficients from a geographical point of view was done according to quantitative categories of hypothetical acting factors and at the same time for every country in the dataset. To illustrate the vast differences among the aviation (infrastructure / traffic) specific indicators, linear scale charts and graphs were made, while the correlation of indicators aggregated by continents was visualized with a logarithmic scaling. 


\section{Introduction}

A recent notable paradox is that the spread of information and communication technologies and devices did not reduce the long-distance mobility and specific travel demand of the people, as was previously assumed (Erdősi 2000, 2010). Though the possibility of teleworking restrained the growth of commuting related travel performances on a global scale, but recreation (as well as training related) mobility and travel attained much larger proportions than the passenger kilometre performance saved this way (Erdősi 2010a).

In contrast to terrestrial and marine transport, the speed and global coverage of aviation makes it significantly more advantageous: airplanes allow the exploration of areas inaccessible by other means (Erdősi 2003a). In our globalizing world, out of all transport subsectors, the performance of air transport rises the most, as it is also the consumer and integrator of most of the $\mathrm{I}+\mathrm{K}$ production (in navigation just as in cabin services or reservation systems - (Hansman 2005). Airbus predicts that between 2012 and 2032, the number of air passengers on Earth will grow from 2.9 billion to 6.7 billion by an average of $4.7 \%$ per annum, and air freight transport will also increase by $4.8 \%$ per year (AIRBUS 2013). More recently, aviation surpassed rail transport in terms of passenger kilometre-performance, even in the main territory of the European Union; in some countries aviation almost outperforms rail transport in terms of the number of passengers.

In contrast to the environmental expectations formulated in the European Union's transport policy (KVM 2001), aviation (and road) traffic continues to grow much faster than GDP. In our view, the "homo technicus" will not be able to reduce the use of aircraft (which far exceed other means of transport in respect of emissions per passenger) in the future either.

The contribution of the air transport sector to GDP, even in the most developed countries, is typically only around $1-3 \%$. However, in some countries, like Dubai, owing to its transfer role resulting from its peculiar geographical position and its prestigious (premium level service provider) international airlines, it reaches $26 \%$. In Iceland, the share of the air transport sector in GDP approached 40\% in 2000; subsequently, as a result of large-scale industrialization (energy-intensive aluminium metallurgy and the installation of IC industries) and the development of high added value sophisticated services and the quaternary sector, this share dropped to $12.9 \%$ in 2011 - that is, to double of the world average (Erdôsi 2015, Owram 2015).

Statistics also show that there are substantial regional differences as regards the development and performance of air transport, which seem incomprehensible at first glance-. However, it is not an easy task for the regionalist researcher to develop correct indicators for these differences, to quantify them with acceptable accuracy, and in particular to reveal the reasons for these differences.

Regional Statistics, Vol 5, No 2. 2015: 82-107; DOI: 10.15196/RS05205 


\section{Objective}

Therefore, in this article, we explore the factors that play a role in the evolution of the intensity of air transport in the individual countries.

It must be made clear that we do not develop a general aviation development index for a given country, because for the calculation of this very complex index number, in addition to the quantitative indices, too many qualitative factors should be considered (for example, the qualitative composition of the aircraft portfolio, the comfort level of airports, the quality of their services, the number and rank of destinations available from the given country, the technical level of air traffic control, the inland availability of the airport, or the dispersion in the income of the population). The problem of assigning weights to a wide variety of qualitative factors cannot be addressed in an exact manner because the choice of weights is a subjective one.

Therefore, in our study, we limit ourselves to determining the airport-supply of air transport and the main specific quantitative indicators of traffic performance in the given countries, and the detection of factors that influence their evolution.

Throughout the world a number of case studies and theoretical works have been published on the interaction between the aviation sector and economic efficiency or performance (for example, ATAG 2012, Morphet-Bottini 2013, Button-Taylor 2000, Ishutkina-Hansman 2009, Erdősi 1998, 1999). These works analyzed the varied (direct, indirect, induced, and catalytic) effects of air transport on a wide spectrum of indicators (ranging from employment to the supply chain). In this paper, we examine another direction of interdependence, namely the extent to which economic and infrastructural factors influence the quantitative indicators of air transport.

\section{The indicators used}

We consider the following indicators as the two basic indicators of air transport supply and (quantitative) development:

- airport-density per unit area or population, and

- airport (total) traffic per unit of population

The first indicator refers to the supply of air transport infrastructure and to the possibility of geographical/physical access to air travel. While the first indicator only demonstrates the potential of air mobility, the latter indicator expresses the degree of actual air mobility, or the yearly frequency of travel of the population and the degree of attraction of visitors from abroad by plane.

To determine the overall density of airports (airport/100,000 km²), we used all airports of a particular country in our calculation (regardless of the length and pavement of runways). This is because even small grassy airports are not without significance, if, in addition to private airplanes, the landing and take-off of aircrafts performing rescue, fire-fighting, forestry/agriculture specialized services, and the aircraft of trainers arriving to hold lectures are considered. To serve scattered settlements that are distant from each other (such as farms, forest depots, power

Regional Statistics, Vol 5, No 2. 2015: 82-107; DOI: 10.15196/RS05205 
distribution centres, power stations, and satellite tracking stations0), the nearby smaller airports are also come in handy.

In contrast to the specific indicators per area for all airports, to the detection of the possibility of involvement in public air traffic, we only used those airports from the airport portfolio that had solid (concrete or asphalt) pavement and at least a minimum 1,523 meter long runway (hereinafter referred to as "large airports") suitable for the landing and take-off of at least medium-sized (over 100 seats) passenger aircrafts (B 737, A 319, A 320), when we determined the number of airports per 1 million population. This is because, in addition to the 1-10 person (propeller or jet) small airplanes, delegation carrier aircraft serving individual and corporate goals and business flight purposes, mostly turboprop or 35 to 70 person ("regional") aircraft are suitable for serving domestic and short international flights can be considered.

The third indicator is the aviation penetration, that is, the air passengers/ population ratio.

\section{Problems of using traffic statistics data (in particular as regards air transport) and some possible solutions}

All transport sub-sectors established sectoral world organizations, in which the countries (with few exceptions) are full members. Therefore they are obliged to provide proper reporting services. Nonetheless, in the international statistical publications of the world organizations, the rubrics of several countries are empty. However, an even greater cause for concern for analysts is that there are unacceptably large differences among data supplied by various organizations (in respect of aviation, the ICAO, the IATA, the EAC, the national statistical offices, the CIA Fact Book, and online statistics) even though they apply to specified concepts and the same year.

On the airport-portfolio of individual countries, the CIA Fact Book gives detailed information by length and cover of runways. However, doubts may arise in relation to their reliability, in particular with regard to the number of unpaved runway airports. It is very likely that in some undeveloped countries with relatively small areas, in addition to the real airports, occasional landing sites were also included in the stock; the strikingly (incredibly) many grassy airports can be attributed to this in such countries not considered to be developed, like Colombia, Bolivia, Papua New Guinea, Paraguay, Sierra Leone, Belize, and El Salvador. (In most countries, however, only those airports appear in the statistics, which meet the criteria set out in the regulations.)

However, in connection with the total airport portfolio, the assessment is doubtful since the lack of adequate data makes it difficult to understand the total air traffic of individual countries. The official (ICAO, Eurocontrol, and IATA) statistical yearbooks merely contain the combined passenger and cargo traffic of airlines registered in the particular country, but not that of foreign airlines. However, the total airport traffic supplemented with the turnover generated by foreign airlines is relevant because it realistically reflects the absolute size of the air mobility, from which a specific intensity indicator per unit of population can be calculated.

Regional Statistics, Vol 5, No 2. 2015: 82-107; DOI: 10.15196/RS05205 
Total airport traffic exceeds the traffic of "home" airlines only in a few countries (Ireland, Iceland, Hungary, and Qatar), mainly because their airlines perform cabotage services abroad without passing through domestic airports. It also happens that foreign airlines make use of the tax deductions of a particular country, if the laws make their registration possible.

Due to the above-mentioned anomalies, we were forced to review the total airport traffic with the summation of partial data that can be found on hundreds of airport websites for all examined countries. We can not hide the fact that, in case of some countries, doubts were raised in connection with the authenticity of airport passenger numbers. According to the overall statistical convention, the total number of boarding and disembarking passengers and (transit) passengers who change to another plane constitute the airport passenger traffic. Other approaches only take into account the boarding (departing) passengers.

Among the acting factors that may have some working hypothesis based (positive or negative) relationship with air performances, world statistics on the road network are available from all countries. However, the International Road Transport Union (IRU) is unable to give an identical structure for the data series of member countries containing very different road types. In this respect, most egregious error is that there are no footnotes that provide the definition of road in the context of the data. In certain countries, only the data of the countrywide (national) network or the data of the whole network (together with local roads) appear in the statistics. Likewise, there are doubts concerning the data of the Fact Book because, during its compilation, the editors did not enforce identical criteria. In connection with the 197 thousand kilometres of road network detected in the case of Hungary, it was revealed that it did not refer to the state road network (30.5 thousand kilometres), but to the entire road network, while the length of network in several densely populated and developed countries is rather small to contain local/regional roads too. It is not clear that what the editors consider to be motorways (for example, the national statistics, in accordance with reality, detect only a few hundred kilometres of motorways in Russia; in contrast with this, the IRU detected more than 39,000 kilometres of motorways, in a way that presumably also included the main priority roads into the calculation, which were widened to $2 \times 2$ lanes in a number of sections.)

\section{The range of countries involved in the evaluation}

Morphet-Bottini (2013) only took into account approximately one-third of the countries in the world for the examination of the relationship between the number of air travels per capita (via national airlines) and GDP per capita. He separated the groups of isolated and non-isolated countries from each other and considered small islands and places where other modes of transport had no significance in passenger transport as isolated places. Likewise, he classified city states with a pre-eminent hub 
function in this category, which due to their unique connectivity form an extremely intense air travel market.

Though our study has a worldwide scope, in order to get a fair assessment and eliminate distortions we did not include the mini-island entities, which are very highly exposed to international tourism into the sample of 168 countries studied in this article (their status is ignored, according to which they can be independent states, overseas provinces, autonomous territories of large states, or commonwealth members). They are predominantly tropical (Caribbean, Pacific, and Indian Ocean based) tourist paradises with small areas and population, where the annual number of tourists arriving by plane (or by cruise ships and yachts) is much larger than the local population. Some of them can be considered tax havens, which also increases their guest traffic. Cyprus, the relatively large island, and Singapore and Hong Kong were excluded from the study since, together with the mini entities, since they not only have outstanding tourism and other kinds of extreme parameters, but towering aviation indicators as well.

However, the island states (New Caledonia, Samoa, Solomon Islands, Jamaica, Trinidad, Brunei), where agricultural, mining, and industrial production activities outperform tourism in terms of value of production were included in the sample of countries assessed. In larger archipelagos, in addition to the regular small and medium-sized aircraft based domestic inter-island air traffic, international air traffic is large and, therefore, the specific airport-density is far above average (for example, in the Philippines).

It is apparent from the extreme values of the indicators of 168 countries displayed in Table 1, that from the indicators of the main factors influencing the density of the air transport infrastructure and the size of the specific passenger traffic, the specific tourist traffic is characterized by the largest (several thousand fold) extremes, while there are several hundred fold differences among the different countries in road vehicle supply and specific GDP and a 120 fold difference in internet penetration. The difference between the extreme values of the specific airport traffic is more than five times larger than the index of the territorial density of the entire airport stock and more than nine times larger than the extremes in the index of the supply with airports that have a solid runway longer than 1,523 meters (In the Fact Book/ICA statistics, the number of runways is included by length categories).

The data used in this study are from between 2010 and 2012 as the same annual data for all countries was not available.

\section{Hypotheses versus calculated results}

Following the production of infrastructure and traffic intensity indicators for air transport and the designation of their most relevant influencing factors, we formulate our assumptions based on our previous professional experiences on the effect of the individual acting-factors (like variables) that influence the indicators and confront them with the results of the correlation calculation.

Regional Statistics, Vol 5, No 2. 2015: 82-107; DOI: 10.15196/RS05205 


\begin{tabular}{|c|c|c|c|c|}
\hline 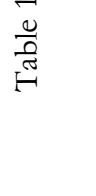 & 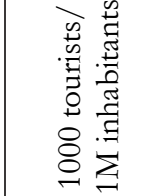 & 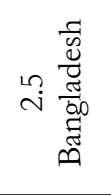 & 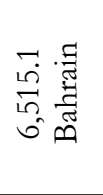 & 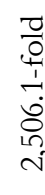 \\
\hline : & 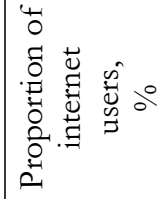 & 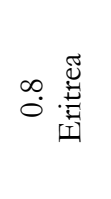 & 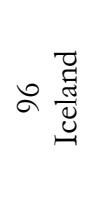 & 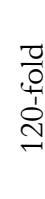 \\
\hline $\begin{array}{l}\frac{\tilde{J}}{\tilde{J}} \\
\tilde{g} \\
\underline{\Xi} \\
. \Xi\end{array}$ & 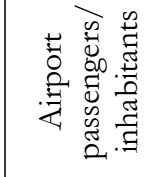 & 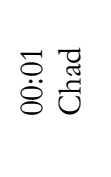 & 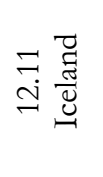 & 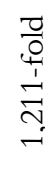 \\
\hline 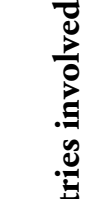 & 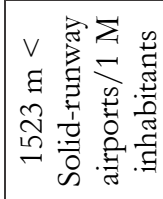 & 它 & 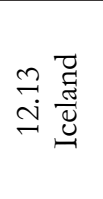 & 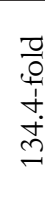 \\
\hline 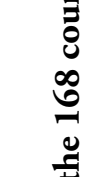 & 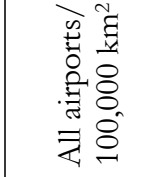 & તે̀ & 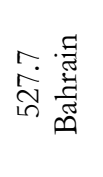 & 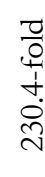 \\
\hline 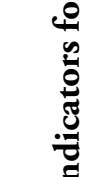 & 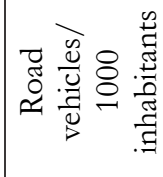 & $\sim \stackrel{8}{\stackrel{8}{\circ}}$ & ڤેे & 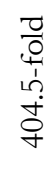 \\
\hline 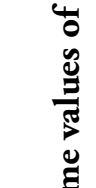 & 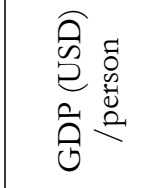 & 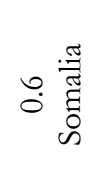 & 守 & $\begin{array}{l}\vec{Z} \\
\stackrel{0}{0} \\
\stackrel{1}{1} \\
\stackrel{\sim}{\sim}\end{array}$ \\
\hline & 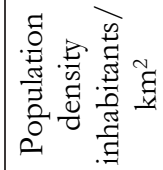 & $\sim \stackrel{\substack{\frac{\pi}{0} \\
\frac{6}{0}}}{\stackrel{0}{\frac{0}{4}}}$ & 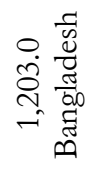 & 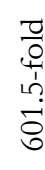 \\
\hline & 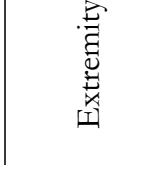 & $\begin{array}{l}\text { 章 } \\
\text { 貝 }\end{array}$ & 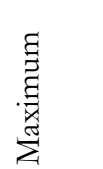 & 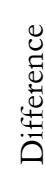 \\
\hline
\end{tabular}


First, we would like to emphasize that we only consider the correlation coefficient as a mathematical theoretical indicator to refer to the stochastic relationship. However, the higher correlation value of the examined factor (variable) does not necessarily mean an actual effect on the analyzed indicator. Thus the reader should not be misled, if hereinafter I write about effect and influence in the text - it is difficult to replace the habitual narrative with another appropriate term. These words are entirely appropriate in case of GDP per capita and the number of tourists (because they actually influence the indicators of the aviation sector), but the other factors only very accidentally influence it - even if their " $\mathrm{r}$ " value is remarkable.

(a) According to the transport-geographical logic and the general experience of the author (mainly concerning domestic and European regions), the following conditions are needed to shape the total number of airports per unit area, and consequently, the supply of the regional aviation infrastructure for a wide variety of aviation purposes:

The greater the area of a country, the more extensive it is, and the greater the distances between the domestic destinations and the peripheral and central regions. Therefore that area where the population needs the closest possible airport for their medium- and long-haul journeys is also larger. In countries with a specifically large area, the provision of state and other administrative services, law enforcement, security, official duties as well as economic activities also require more airports per unit area than in small countries.

Table 2

Correlation coefficients for the 168 countries

\begin{tabular}{l|c|c|c}
\hline \multicolumn{1}{c|}{ Variables } & $\begin{array}{c}\text { All airports/ } \\
100,000 \mathrm{~km}^{2}\end{array}$ & $\begin{array}{c}\text { Runway of } \\
\text { more than } \\
1523 \mathrm{~m} / 1 \mathrm{M} \\
\text { inhabitants }\end{array}$ & $\begin{array}{c}\text { Airport } \\
\text { passengers/ } \\
\text { inhabitants }\end{array}$ \\
\hline Area $\left(\mathrm{km}^{2}\right)$ & -0.149 & 0.155 & 0.040 \\
Population density (people $\left./ \mathrm{km}^{2}\right)$ & 0.040 & -0.445 & -0.257 \\
$\mathrm{GDP} /$ capita (USD) & 0.379 & $0.877^{* *}$ & $0.916^{* *}$ \\
Road/100 km ${ }^{2}$ & 0.332 & 0.124 & 0.178 \\
Motorway, $\mathrm{m} / \mathrm{km}^{2}$ & 0.406 & -0.048 & 0.266 \\
Automobile/1000 inhabitants & 0.380 & $0.862^{* *}$ & $0.932^{* *}$ \\
Railroad, km/100,000 km ${ }^{2}$ & 0.492 & 0.030 & 0.320 \\
Internet users, \% & 0.292 & $0.826^{* *}$ & $0.860^{* *}$ \\
Foreign tourists/residents & 0.255 & 0.326 & 0.495 \\
All airports/100,000 km ${ }^{2}$ & - & 0.109 & 0.204 \\
With a runway longer than & & & $0.908^{* *}$ \\
1523 meters/1M inhabitants & 0.109 & - & - \\
Airport passengers/inhabitants & 0.204 & $0.908^{* *}$ & \\
$\quad$ ** A very close correlation. & & & \\
$\quad$ Source: Edited from calculations by Peter Dombi. & & & \\
\end{tabular}

Regional Statistics, Vol 5, No 2. 2015: 82-107; DOI: 10.15196/RS05205 
The calculation, however, showed (Table 2) negligible negative values $(\mathrm{r}=-0.149)$; that is, the calculation wholly refutes our hypothesis. (Of course, it is an interesting question that how much the weighting with the size of the area would have reduced the anomalies). However, if we disregard the problem of accuracy of the basic data, the result can be attributed to the fact that in a number of large countries, economic and transport activities have low intensities in large areas due to highly unfavourable natural conditions (such as deserts or wastelands) and/or weak economic conditions.

The state is unable to maintain the expected number of airports as public services (for example, in Russia and Kazakhstan, the stock of small airports has decreased significantly since the disintegration of the Soviet Union), while the private sector operates on the basis of ROI (return on investment) and profits.

- Due to the foregoing reasons, there is some degree of inverse relationship with the population density since airports are indispensable in the civilized world to the transport, communication, and supply of inhabitants in sparsely and 'punctiform' populated areas in the absence of other long-distance transport modes (even in the underdeveloped countries, in addition to the public air services, hundreds of "bush pilots" carry out air taxi services).

From the $\mathrm{R}=0.040$ value, we can say that our hypothesis was somewhat idealistic, because we previously overestimated the presumed spontaneous and (state influenced) planned supply of airports in sparsely populated areas as compared to the actual situation.

- We expect that the density pf airports would increase with the GDP per capita. This is because, on the demand side, a more affluent population, has a greater average demand for airports in reasonable proximity providing commercial air services (private and business purposes, public use, scheduled / charter); on the other hand, the higher income also should have a beneficial effect on the density of airports that serve general aviation purposes and are intended to provide various special public services on corporate and private airports. The strengthening of financial conditions may stimulate the establishment of additional airports and an increase in supply.

This conclusion, however, is not supported by the $r=0.379$ value.

According to our hypothesis, the airport-density indicator is less influenced as compared to the previous two indicators by the following factors:

- Density and quality of the terrestrial transport infrastructure network. In many countries, there is no rail transport and there are extensive areas that are not accessible on traditional paved roads suitable for cars. In these areas, only airports provide an opportunity for physical relations.

Nonetheless, there is a loose correlation with road density $\mathrm{r}=0.332$, motorways $r=0.406$, the vehicle stock $r=0.380$, and railways $r=0.492$.

Regional Statistics, Vol 5, No 2. 2015: 82-107; DOI: 10.15196/RS05205 
- The specific number of foreign tourists also does not affect the density of the airport portfolio. The emerging/developing countries are particularly characterized by the fact that foreign tourists predominantly arrive at some busy airports that serve the most significant resort havens. Undoubtedly, there are also several exclusive resorts providing sophisticated services away from the settlements, to where (to the nearby small grassy airports) the high society guests and villa owners arrive with private aircrafts. Nevertheless, the number of these is dwarfed by the participants of mass tourism, which is in the order of tens of millions.

In accordance with the assumption, worldwide tourism hardly affects the density of the entire airport portfolio, $r=0.255$.

- In principle, the proportion of internet users cannot influence (directly) the density of the entire airport portfolio, because the use of the World Wide Web depends on GDP per capita, the level of education, the information and communication development policy of the given country, and on the interests of service provider companies.

Nonetheless, the $r=0.292$ value implies that the examined indicator is not totally independent from use of the World Wide Web. This may arise because in countries with a denser airport-portfolio other factors play an indirect role in the average and above average frequency of internet use.

b) Presumably the specific supply (for potential passengers) of airports with a solid runway of at least $1523 \mathrm{~m}$ (hereinafter referred to as "large" airports) are indispensable to commercial air travel

- This is primarily determined by the level of economic development of the given country (measured in GDP per capita). This assumption proved to be well founded as the related $r=0.847$.

- From the hypothetical impact factors, the specific number of foreign tourists was classified in second place. This assumption was not convincingly confirmed by the $r=0.326$ value.

- In third place, we assumed a strong correlation between the specific airport traffic (airport passengers/inhabitants) and the large airport supply. The relationship between the two factors is stronger than expected, with $r=0.908$.

- The size of the area, which was believed to be the fourth most important factor, can be practically ignored as its coefficient is only $r=0.155$.

- Among the other (traffic) factors, the calculation only confirmed the role of vehicle supply $(r=0.862)$, but not of motorways $(r=-0.048)$, while we do not attach practical importance to the (formally) significant correlation with the internet $(r=0.826)$.

c) According to our assumption, the following were the most important factors that influence the evolution of specific air traffic that is also known as the number of passengers-penetration (total number of airport passengers per one inhabitant):

Regional Statistics, Vol 5, No 2. 2015: 82-107; DOI: 10.15196/RS05205 
- On the supply side

- The specific value of large airports is suitable for the traffic of scheduled domestic and international commercial air flights, and

- The number of city pairs linked with scheduled air services (domestic and international relations).

- On the demand side

- GDP per capita (indirectly the income levels),

- $\quad$ number of foreign visitors (mostly tourists),

- $\quad$ the size of the country's territory, and the

- $\quad$ specific complete airport density was selected.

Among the supply-side factors, we only evaluated the first factor and not the production of the second indicator (partially due to deficiencies in basic data and partially due to the extremely time-consuming nature of data collection).

The specific indicator of airports suitable for regular commercial air transport is considered as the basic measure of the supply of services. However, it can not be neglected that the geographical location and capacity of airports must fit the structure of the settlement network and the geographical distribution of the population. The huge airport capacity utilization of cities and metropolises mostly located near coastlines has better chances than that of medium or small (counting only 50 to 200 thousand passengers per year) airports located in sparsely populated areas, which were established so far from each other that they are also available from the edge of their extensive catchment areas by (potential) passengers still within an acceptable period of time. As regards the geographical distribution of travel demand (and the number of available destinations) and the frequency of service, there are large differences between the airports adjacent to large cities of rich supply, which are heavily concentrated in space, and the smaller rural airports. Insofar as there are many of the latter group (for example, in countries with an area of several million square $\mathrm{km}$ ) the rationality requires that their destination supply should be sufficiently diversified to reduce the reliance on large airports. However, this requirement prevails in few places, and therefore, passengers are forced to travel to the big cities near coastal areas from the vast, sparsely populated inner areas despite the high cost and time expenses (in good case with domestic feeder flights or only relying on land vehicles) when they do not buy a ticket for a neighbourhood international flight.

The above mentioned hypotheses are verified by our calculations. There is a very strong correlation between the supply with larger airports and air traffic: $\mathrm{r}=0.908$.

On the demand side, GDP per capita (with its push-pull effects depending on its size) usually affects the flow of traffic strongly. In high-income countries, the traffic generated by those travelling abroad for private (predominantly leisure) purposes is several times higher than the number of people travelling for professional purposes. In certain countries, such as those in Western Europe and the Gulf, the regular movement of migrant workers is significant. In case of a number of countries with

Regional Statistics, Vol 5, No 2. 2015: 82-107; DOI: 10.15196/RS05205 
poor economic performance measured by GDP per capita, the following may cause relatively large airport traffic:

- employees, university, and college students flowing out regularly and in large numbers (not too far away from the advanced host/employing areas)

- recreation tourists (much less affected by the distance) arriving en masse from the advanced host countries (seasonally depending on the climate or the season).

These result in

- a very close correlation $(\mathrm{r}=0.916)$ between the specific airport passenger traffic and GDP per capita, and

- an insignificant or loose worldwide connection $(r=0.495)$ between the passenger traffic and the specific tourist traffic.

Basically, the size of the country's territory is relevant for the generation of domestic air traffic. In very large countries, the distances between the departure and destination stations are so big that the demand for airplane travel should have been higher merely based on the consideration of geographical distance as compared to smaller countries that are otherwise similar as regards other indicators. However, in a number of countries with an expressly large area, the average earnings of the population, and therefore its air mobility, is moderate.

The very low value of the coefficient $(r=0.040)$ refers to this latter essential condition, that is there is no demonstrable relationship between the size of the area and the specific air traffic. This may partly be explained by the fact that the shape of countries also modifies the demand for air transport; for example, several pubic airports operate in Greece, with its dozen islands, in the long stretch of Norway, and in the sickle-shaped Croatia.

According to our assumption, population density in itself cannot substantially modify the specific air traffic, since the level of economic development of the examined country is virtually independent of the population density. This assumption was dramatically confirmed: there is no relationship between specific GDP and population density; the value of $r$ was only 0.140 , and therefore, the relationship with air traffic was also very loose $(r=0.257)$.

According to our assumption, the density of the traditional land transport infrastructure network (similar to the coefficient value of 0.204 of airport density) may have a rather weak direct impact on the total air traffic of countries. Their indirect effects, namely, their (feeder and take-away) role in the ground accessibility of airports is not negligible:

- the indicator of the traditional national road density is $r=0.312$,

- the indicator of motorways is $\mathrm{r}=0.369$, which indicates a loose correlation,

- the indicator for vehicle supply $(\mathrm{r}=0.731)$ shows a detectable connection,

- the indicator for the potential rail network had an $r=0.215$.

Regional Statistics, Vol 5, No 2. 2015: 82-107; DOI: 10.15196/RS05205 
Therefore, we can conclude that the density of motorways and high-speed rail (not included in the study), through their integration of the biggest airports, contribute significantly to air traffic generation; this is due to the fact that they are able to extend the catchment areas of their beneficiary airports to large areas.

\section{A more detailed analysis of some connections according to quantitative categories and geographical distribution and results}

Behind the global average data of factors that affect air travel, strong dispersions are displayed according to quantitative categories and geographic presence in more detailed calculations. In this study, we cannot analyse the relationships among all factors. Therefore, we limit ourselves to the analysis of only the most important factors in terms of the topic, and in the interests of transparency and compression we illustrate this with spreadsheets that contain large amounts of information and correlation graph curves.

The data in Table 2 show that there are highly significant (sometimes drastic) differences in the closeness of correlation.

Factors that influence the geographic density of the total airport portfolio are the relatively most balanced (at a low level and only with negative correlation) with a variance between 0.040 and 0.492 . They do not display very strong correlation. The column (2) for the indicators on large airports contains, as an extreme case, two negative values and three very strong correlations too. Positive values are dispersed between 0.048 and 0.827 (in a much greater extent as compared to that in the first column).

Against a negative value, the column of passenger penetration contains four very strong correlations. As compared to other indicators, the dispersion of positive values between 0.040 and 0.932 shows the most extreme coefficients.

In Tables 3-5 on individual indicators, in addition to the categories of variables, the number of countries associated with them, and the arithmetic average of the examined (air) indicator, we also include the (arithmetic) average weighted with the population numbers of countries and the extreme values of the (air) indicator and their differences. The last column contains the degree of concentration of values below a certain maximum (as a percentage).

We used detailed linear charts (functions) for the graphical visualization (to illustrate the incredible extremes-like the points concentrated close to the origo and extremely high outlier values). Furthermore, for review of the data, logarithmic graphs that contain the positions of all countries are also included. 
Changes in the supply of large airports per million inhabitants as a function of categories of GDP per capita and their geographical dispersion

Table 3 contains 168 countries surveyed classified in 8 categories of GDP per capita. Among the higher categories, the number of countries grows less than the average weighted with the population numbers of countries belonging to the given category due to countries with a large population.

Figure 1

\section{Supply with large airports as a function of GDP per capita}

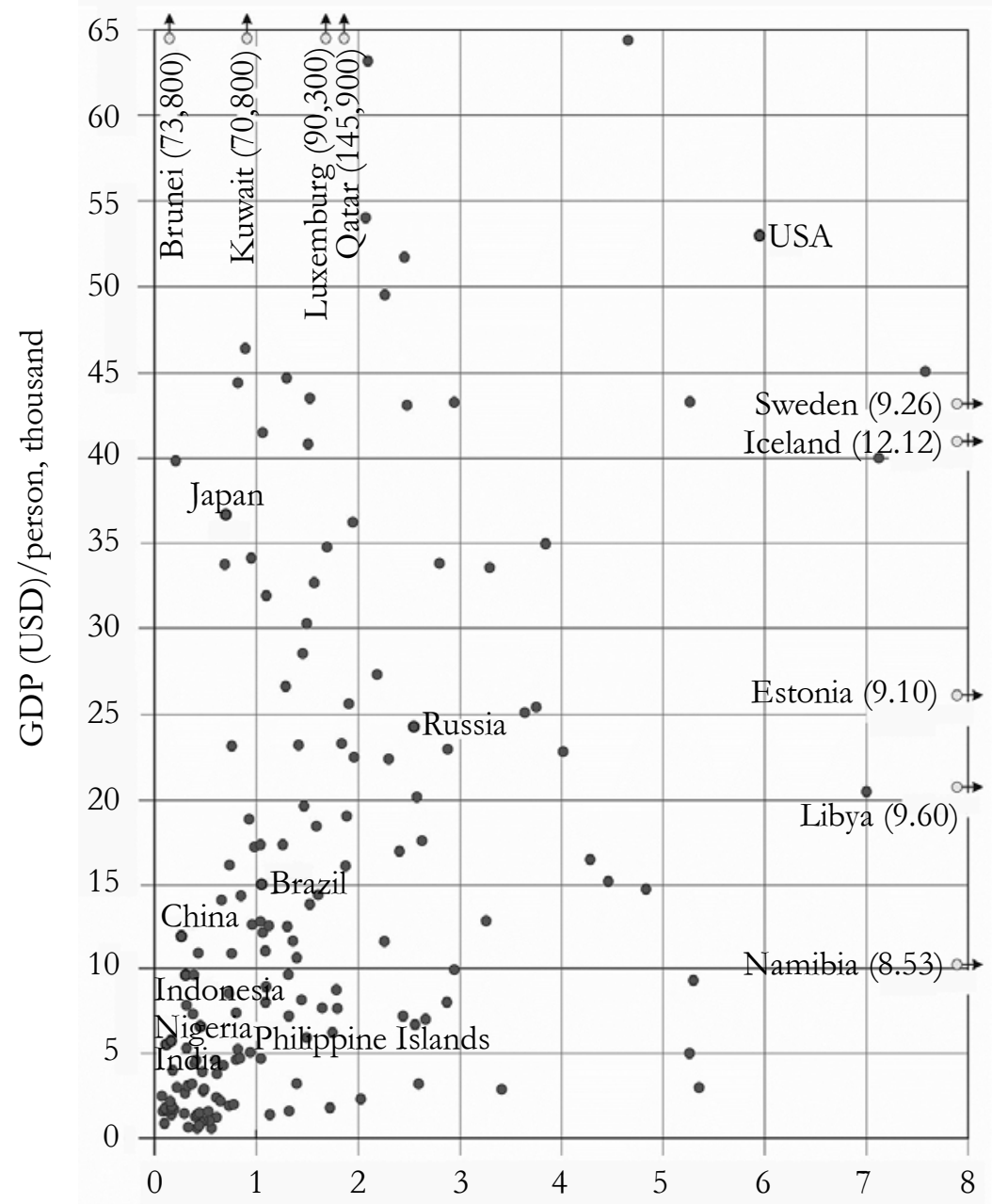

Airports with a paved runway longer than 1523 meters/1M inhabitants 
Though the differences between extreme values of the supply are highly volatile by the GDP category, but a slightly downward trend is perceptible toward the highest category.

- In the majority of lowermost category countries with an extremely weak economy (maximum 2500 USD GDP/inhabitant) mainly in sub-Saharan Africa and to a lesser extent in Asia, against the specific condition level, the supply of airports is actually insensitive up to the level of 0.60 . On a linearly scaled graph the points indicating the values are strongly grouped together besides the ordinate (Figure 1).

- From the loose array of countries with a very weak economy in the category of 2500-5000 USD/inhabitant, the supply indicator of three small tropical countries significantly stands out.

- In the stock of poor condition countries (5,000 to 10,000 USD/inhabitant), the average indicator with a value of 1.36 is slightly above that of the former category (Table 3). The high weighted average can be traced back to 4 highly populous countries (Figure 1).

- The group with an economic strength of 10,000-20,000 USD/inhabitant is made up by emerging and, in worldwide comparison, mid-developed countries with airport indicators ranging from 0.26 to 11.0 , with an average of 1.85. In this circle, Europe is represented only by the Balkan countries.

- In the category of 20,000-30,000 USD/inhabitant, which consists of half dozen countries, there are countries that are in a better financial position than the world average and have a strong tourist attraction. Half of these countries are European countries, with Malaysia and Libya strongly sticking out from this crowd (Table 3).

- The difference between the arithmetic and the weighted average in the bloc of dozens of advanced and highly developed countries, that is, in the group with an economic performance of 30,000-40,000 USD/inhabitant can be traced back to Japan, which has a population of 120 million.

- In the group with GDP per capita between 40,000-50,000 USD, Europe is represented by the Netherlands, Sweden, Austria, and Iceland with an average of 2.84 .

- In the group of over USD 50,000, Europe is represented by Norway and Luxembourg. Furthermore, there are some rich oil-producing Asian countries. The remarkably high value of the weighted average is attributable to the fact that the United States, with its 320 million people, is also included here. 
Table 3

Indicators on supply with (large) airports having a solid runway longer than 1523 meters per 1 million population for each category of GDP per capita

\begin{tabular}{|c|c|c|c|c|c|c|}
\hline \multirow[b]{2}{*}{$\begin{array}{l}\text { GDP (USD) } \\
\text { /person }\end{array}$} & \multirow{2}{*}{\begin{tabular}{|c|} 
Number of \\
countries
\end{tabular}} & \multirow{2}{*}{$\begin{array}{c}\text { Airport } \\
\text { supply } \\
\text { a) arithmetic } \\
\text { average } \\
\text { b) weighted* } \\
\text { arithmetical } \\
\text { average }\end{array}$} & \multicolumn{3}{|c|}{ Extremities } & \multirow[b]{2}{*}{ Frequency** } \\
\hline & & & minimum** & maximum $* *$ & difference & \\
\hline $2,500>$ & 34 & $\begin{array}{l}\text { a) } .54 \\
\text { b) } 13.05\end{array}$ & $\begin{array}{l}0.07 \\
\text { Tadzhikista } \\
\text { n }\end{array}$ & $\begin{array}{l}2.03 \\
\text { Papua New } \\
\text { Guinea }\end{array}$ & 69-fold & $\begin{array}{l}\operatorname{Max} 0.5 \\
60.6 \%\end{array}$ \\
\hline $2,500-5,000$ & 22 & $\begin{array}{l}\text { a) } 1.30 \\
\text { b) } 11.16\end{array}$ & $\begin{array}{l}0.18 \\
\text { Ghana }\end{array}$ & $\begin{array}{l}5.26 \\
\text { Samoa }\end{array}$ & 29-fold & $\begin{array}{l}\operatorname{Max} 1.0 \\
71.4 \%\end{array}$ \\
\hline $5,000-10,000$ & 27 & $\begin{array}{l}\text { a) } 1.36 \\
\text { b) } 18.20\end{array}$ & $\begin{array}{l}0.12 \\
\text { India }\end{array}$ & $\begin{array}{l}5.30 \\
\text { Mongolia }\end{array}$ & 2.29-fold & $\begin{array}{l}\operatorname{Max} 1.5 \\
63.0 \%\end{array}$ \\
\hline $10,000-20,000$ & 33 & $\begin{array}{l}\text { a) } 1.85 \\
\text { b) } 24.54\end{array}$ & $\begin{array}{l}0.26 \\
\text { China }\end{array}$ & $\begin{array}{l}11.00 \\
\text { Dominica }\end{array}$ & 44.2-fold & $\begin{array}{l}\operatorname{Max} 1.5 \\
60.6 \%\end{array}$ \\
\hline $20,000-30,000$ & 18 & $\begin{array}{l}\text { a) } 3.35 \\
\text { b) } 14.47\end{array}$ & $\begin{array}{l}0.76 \\
\text { Malaysia }\end{array}$ & $\begin{array}{l}9.60 \\
\text { Libya }\end{array}$ & 42.3-fold & $\begin{array}{l}\text { Max } 3.0 \\
66.7 \%\end{array}$ \\
\hline $30,000-40,000$ & 12 & $\begin{array}{l}\text { a) } 1.85 \\
\text { b) } 23.02\end{array}$ & $\begin{array}{l}0.21 \\
\text { France }\end{array}$ & $\begin{array}{l}7.12 \\
\text { Finland }\end{array}$ & 33.9-fold & $\begin{array}{l}\operatorname{Max} 2.0 \\
66.8 \%\end{array}$ \\
\hline $40,000-50,000$ & 13 & $\begin{array}{l}\text { a) } 2.84 \\
\text { b) } 18.35\end{array}$ & $\begin{array}{l}0.82 \\
\text { Austria }\end{array}$ & $\begin{array}{l}12.12 \\
\text { Iceland }\end{array}$ & 14.8-fold & $\begin{array}{l}\text { Max } 3.0 \\
69.2 \%\end{array}$ \\
\hline $50,000<$ & 9 & $\begin{array}{l}\text { a) } 2.46 \\
\text { b) } 92.57\end{array}$ & $\begin{array}{l}0.26 \\
\text { Brunei }\end{array}$ & $\begin{array}{l}5.96 \\
\text { USA }\end{array}$ & 22.9-fold & $\begin{array}{l}\operatorname{Max} 3.0 \\
77.8 \%\end{array}$ \\
\hline
\end{tabular}

* Weighted with population numbers.

** Based on national original supply indicators (without weighting).

Source: calculations and editing of the author (from basic data of the Fact Book and other sources).

Figure 2 illustrates on a logarithmic scale the distribution of the GDP-dependent supply of large airports in some parts of the world. 


\section{Distribution of the relationship between major airports and GDP per capita by continent on a logarithmic scale}

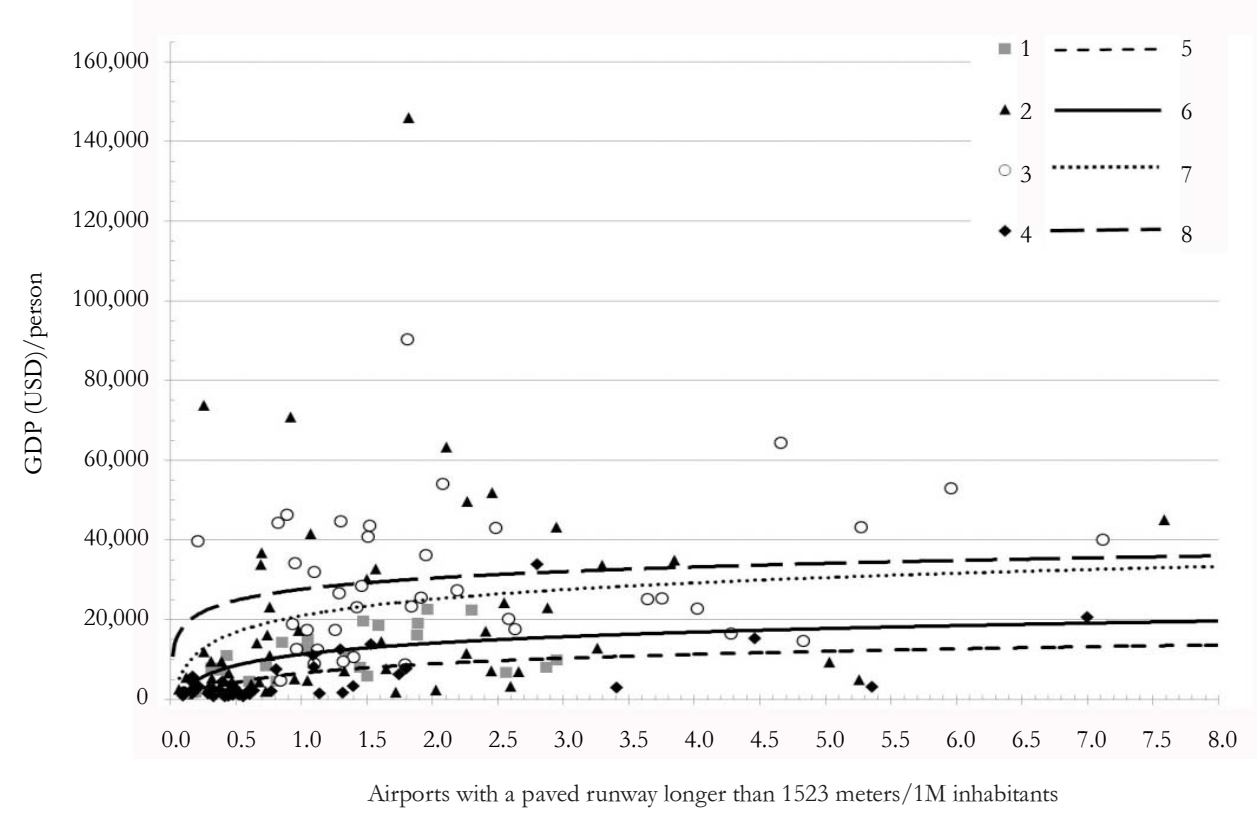

Legend: designation of individual countries: 1 - Latin American, 2 - Asian/Oceanian, 3 - European and North American, 4 - African. Log trend line of R2 concerning 5 - Latin America, 6 - Asia/Oceania, 7 - Europe and North America, 8 - Africa.

Source: Edited by Aron Kovács.

Developments in specific airport passenger traffic as a function of categories of GDP per capita and their geographical dispersion

In Table 4, the arithmetic average of the indicator for specific airport traffic shows a clear upward trend towards the highest GDP per capita category, in contrast with the weighted average which varies rhapsodically (because of the weight of particularly populous countries determining the third, fourth, and highest categories). The differences between the extreme values of individual categories show a downward trend towards the highest GDP per capita.

- The effect on GDP is least reflected among extremely weak countries included in the lowest category of less than 2500 USD GDP per capita. Insensitivity towards GDP is manifested in special aggregates, most markedly in countries with GDP per capita of around 1400 USD and between USD 1800-1900. In the vast majority of countries with GDP per capita under 1900 USD, the traffic is below the 0.1 value. 
Indicators on specific airport passenger traffic

Table 4 for each category of GDP per capita

\begin{tabular}{|c|c|c|c|c|c|c|}
\hline \multirow[b]{2}{*}{$\begin{array}{c}\text { GDP per capita } \\
\text { (USD/ } \\
\text { inhabitants) }\end{array}$} & \multirow{2}{*}{$\begin{array}{c}\text { Number of } \\
\text { countries }\end{array}$} & \multirow{2}{*}{$\begin{array}{c}\text { Airport } \\
\text { passengers / } \\
\text { inhabitants } \\
\text { c) arithmetic } \\
\text { average } \\
\text { d) weighted* } \\
\text { arithmetical } \\
\text { average }\end{array}$} & \multicolumn{3}{|c|}{ Extremities** } & \multirow[b]{2}{*}{ Frequency** } \\
\hline & & & minimum & maximum & difference & \\
\hline $2,500>$ & 34 & $\begin{array}{l}\text { a) } 0.09 \\
\text { b) } 13.02\end{array}$ & $\begin{array}{l}0.01 \\
\text { Chad }(+3)\end{array}$ & $\begin{array}{l}0.69 \\
\text { Solomon } \\
\text { Islands }\end{array}$ & 69-fold & $\begin{array}{l}\text { Max } 0.1 \\
77.0 \%\end{array}$ \\
\hline $2,500-5,000$ & 23 & $\begin{array}{l}\text { a) } 0.28 \\
\text { b) } 10.86\end{array}$ & $\begin{array}{l}0.04 \\
\text { Zambia }\end{array}$ & $\begin{array}{l}1.58 \\
\text { Samoa }\end{array}$ & 158- fold & $\begin{array}{l}\text { Max } 0.2 \\
54.5 \%\end{array}$ \\
\hline $5,000-10,000$ & 28 & $\begin{array}{l}\text { a) } 0.46 \\
\text { b) } 46.65\end{array}$ & $\begin{array}{l}0.09 \\
\text { Swaziland }\end{array}$ & $\begin{array}{l}2.65 \\
\text { Belize }\end{array}$ & 29.4-fold & $\begin{array}{l}\text { Max } 0.5 \\
74.1 \%\end{array}$ \\
\hline $10,000-20,000$ & 33 & $\begin{array}{l}\text { a) } 0.88 \\
\text { b) } 59.00\end{array}$ & $\begin{array}{l}0.06 \\
\text { Iraq }\end{array}$ & $\begin{array}{l}2.26 \\
\text { Panama }\end{array}$ & 37.7-fold & $\begin{array}{l}\text { Max } 1.0 \\
72.7 \%\end{array}$ \\
\hline $20,000-30,000$ & 18 & $\begin{array}{l}\text { a) } 1.29 \\
\text { b) } 13.83\end{array}$ & $\begin{array}{l}0.26 \\
\text { Slovakia }\end{array}$ & $\begin{array}{l}3.05 \\
\text { Portugal }\end{array}$ & 11.7-fold & $\begin{array}{l}\text { Max 1.2 } \\
63.2 \%\end{array}$ \\
\hline $30,000-45,000$ & 22 & $\begin{array}{l}\text { a) } 3.90 \\
\text { b) } 22.06\end{array}$ & $\begin{array}{l}0.28 \\
\text { Equatorial- } \\
\text { Guinea }\end{array}$ & $\begin{array}{l}6.98 \\
\text { New } \\
\text { Zealand }\end{array}$ & 24.5-fold & $\begin{array}{l}\operatorname{Max} 3.5 \\
66.7 \%\end{array}$ \\
\hline $45,000<$ & 10 & $\begin{array}{l}\text { a) } 5.10 \\
\text { b) } 32.06\end{array}$ & $\begin{array}{l}1.95 \\
\text { Saudi } \\
\text { Arabia }\end{array}$ & $\begin{array}{l}10.60 \\
\text { Qatar }\end{array}$ & 5.4-fold & $\begin{array}{l}\operatorname{Max} 9.0 \\
62.5 \%\end{array}$ \\
\hline
\end{tabular}

* Weighted with population numbers. ** National coverage indicators without weighting.

Source: Calculations and editing of the author (basic data deriving from a variety of sources).

- Though the arithmetic average ( 0.28 or 0.46$)$ of traffic intensity in very poor and weak countries with a GDP per person of between 2,500 and 5,000, and between 5,000 and 10,000 USD is several times higher than that in the lowest category. However, nearly a dozen countries among these (such as Zambia and India) still remain within the traffic category of 0.1. Belize, the Fiji Islands, Jamaica, and Puerto Rico are characterized by the highest traffic values (1.9 to 2.65).

The positive effect of GDP growth on traffic gradually begins to become more and more important (but not in a linear fashion) among countries with a GDP per capita figure of over 10,000.

- Independent countries with the world average medium specific economic performance of 10,000-20,000 USD GDP per person have traffic intensity indicators below the 2.4 value, while their average is 0.88 . Within this grouping, the lower sub category is made up by the conglomeration of

Regional Statistics, Vol 5, No 2. 2015: 82-107; DOI: 10.15196/RS05205 
countries with USD 10,200 to 13,000 GDP per capita, whose traffic intensity is limited to values between 0.3 and 1.0. The members of the upper subcategory with USD 13,000 to 20,000 GDP per capita differ from the former in that their indicators are strongly dispersed (between 0.2 and 2.4). Among the members of the intensity range between 1.0 and 2.26 in Iraq, ongoing conflicts, armed clashes, and a series of attacks reduce traffic. Additionally, few people use air transport in the rather dictatorially governed Algeria, which is faced with problems of internal security (job-takers in Southern Europe, particularly in France, prefer the cheaper sea ferries to their occasional journeys).

- Relatively few countries, which are predominantly not far behind the threshold of the category of developed countries, are in the group of countries with an economic performance of between USD 20,000 and 30,000 GDP per person. Traffic intensity indicators of the independent countries variously evolve between 0.25 (Slovakia) and 3.05 (Portugal), that is, they are highly dispersed. The average of this category is 1.29 .

- The (super rich) independent countries with over 45,000 USD GDP per person show very strong extremes not only as regards area, population, and population density, but the base of their economies is also very different: from oil producers in the Persian Gulf area to countries with diversified economic structure, in which, high value-added services predominate.

Figure 3

\section{Relationship between GDP per capita and airport passenger penetration}

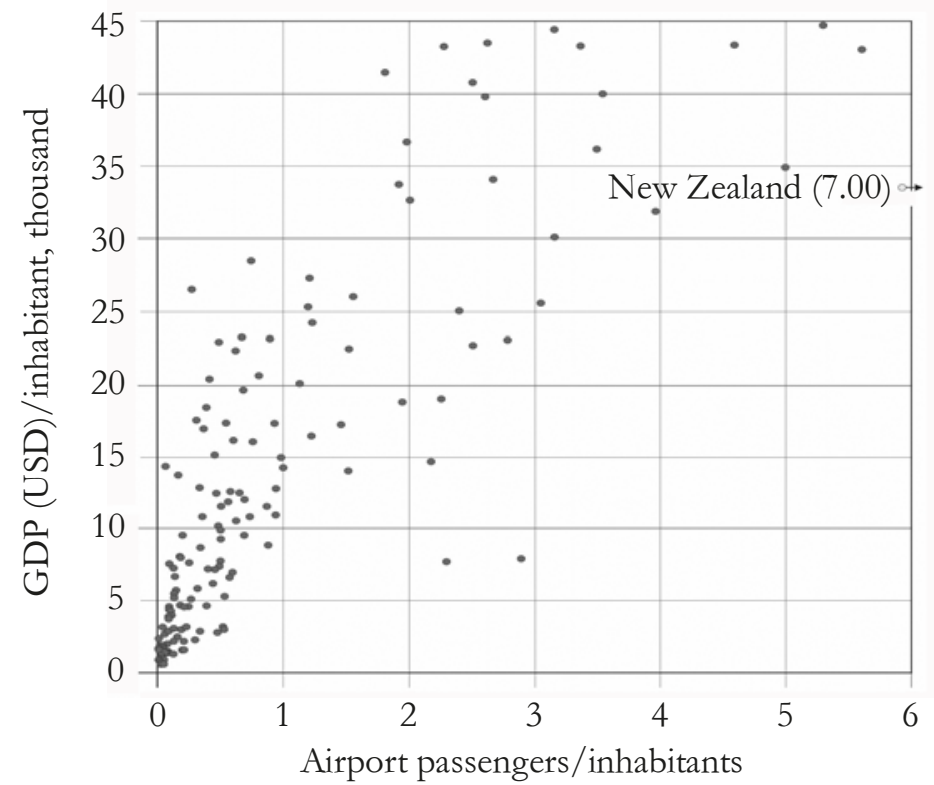

Source: Edited by the author.

Regional Statistics, Vol 5, No 2. 2015: 82-107; DOI: 10.15196/RS05205 
Figure 4 illustrates the distribution of the GDP dependent evolution of the airport passenger penetration on a logarithmic scale by continents.

\section{Relationship between airport passenger penetration and \\ GDP per capita on a logarithmic scale by continent}

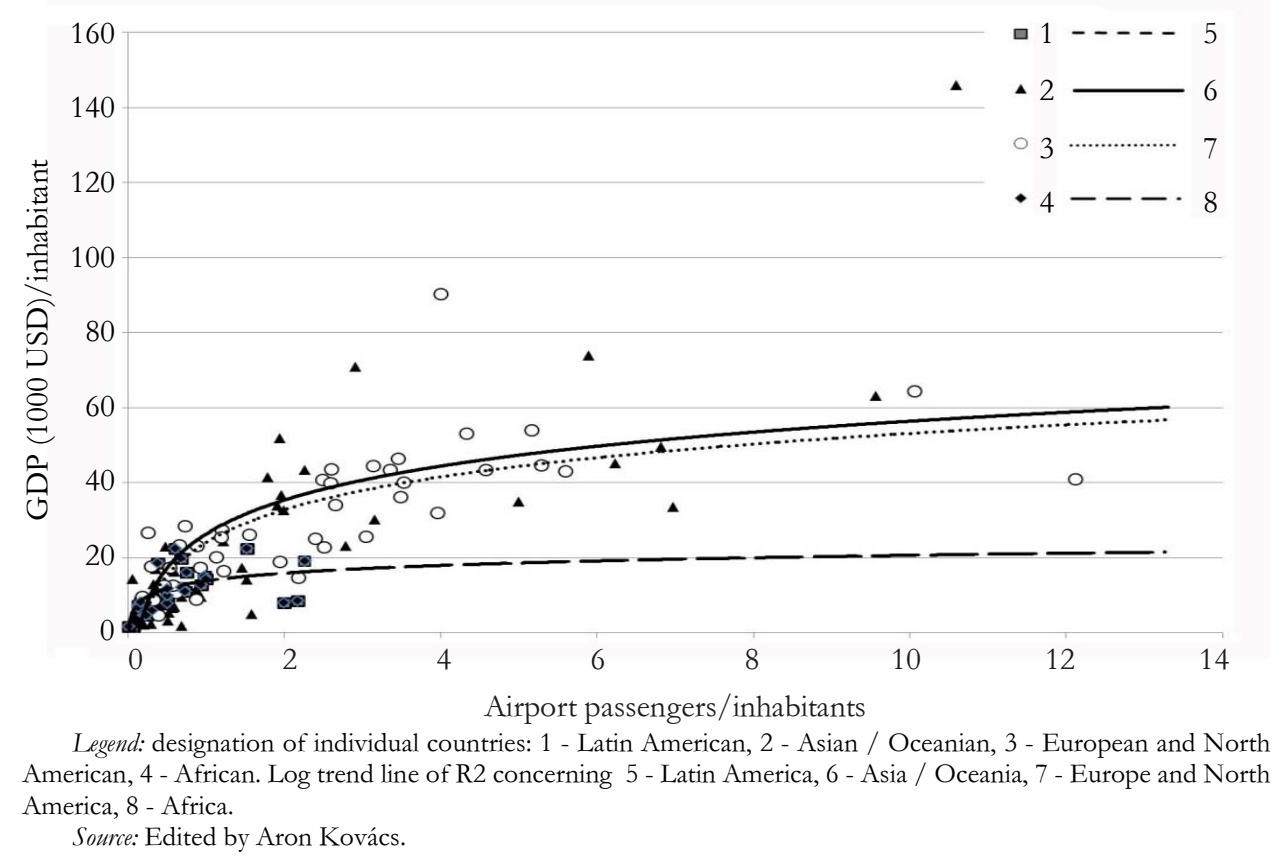

Changes in the intensity of specific airport passenger traffic as a function of specific tourist traffic

Table 5 contains the size of the specific tourist traffic sorted by 6 categories. The number of countries that belong to the individual categories decreases quite regularly and significantly towards the highest value category, while the arithmetic average of the specific airport passenger traffic (a generally strong relationship due to a high correlation coefficient) shows a dynamically growing trend. In contrast with the former, however, the weighted arithmetic average of the turnover shows a strongly decreasing trend regarding the number of countries belonging to the individual categories. There is no any regularity in the development of differences between the extreme values.

a) In four-fifths of the 53 countries that generate an extremely low tourist traffic (less than 50 thousand persons/one million inhabitants), specific airport traffic had a value of less than 0.3 , while their arithmetical average was only slightly higher than 0.20 . The difference between the arithmetic and the weighted arithmetic mean (Table 5) is by far the biggest in this category, mainly due to China and Brazil. 
Indicators of specific airport passenger traffic

Table 5 in the categories of specific tourist numbers

\begin{tabular}{|c|c|c|c|c|c|c|}
\hline \multirow[b]{2}{*}{$\begin{array}{l}\text { Number of } \\
\text { tourists, } 1,000 \\
\text { persons, } \\
\text { per } 1 \text { million } \\
\text { population }\end{array}$} & \multirow[b]{2}{*}{$\begin{array}{c}\text { Number of } \\
\text { countries }\end{array}$} & \multirow{2}{*}{$\begin{array}{c}\text { Airport } \\
\text { passengers } \\
\text { /inhabitants } \\
\text { e) arith- } \\
\text { metic } \\
\text { average } \\
\text { f) weighted* } \\
\text { arithmetical } \\
\text { average }\end{array}$} & \multicolumn{3}{|c|}{ Extremities $^{* *}$} & \multirow[b]{2}{*}{ Frequency $^{* *}$} \\
\hline & & & minimum & maximum & difference & \\
\hline $2.5-\quad 50.0$ & 53 & $\begin{array}{l}\text { a) } 0.21 \\
\text { b) } 136.54\end{array}$ & $\begin{array}{l}0.01 \\
\text { Haiti }(+3)\end{array}$ & $\begin{array}{l}0.98 \\
\text { Brunei }\end{array}$ & 98-fold & $\begin{array}{l}\text { Max } 0.3 \\
80.7 \%\end{array}$ \\
\hline $50.0-250.0$ & 45 & $\begin{array}{l}\text { a) } 0.60 \\
\text { b) } 91.11\end{array}$ & $\begin{array}{l}0.01 \\
\text { Ruanda }\end{array}$ & $\begin{array}{l}2.59 \\
\text { France }\end{array}$ & 259-fold & $\begin{array}{l}\text { Max } 0.5 \\
68.2 \%\end{array}$ \\
\hline $250.0-500.0$ & 24 & $\begin{array}{l}\text { a) } 1.82 \\
\text { b) } 26.92 \\
\end{array}$ & $\begin{array}{l}0.18 \\
\text { Laos } \\
\end{array}$ & $\begin{array}{l}6.24 \\
\text { Australia }\end{array}$ & 34.7-fold & $\begin{array}{l}\text { Max } 1.5 \\
50.0 \% \\
\end{array}$ \\
\hline $500.0-1000.0$ & 26 & $\begin{array}{l}\text { a) } 2.55 \\
\text { b) } 8.89 \\
\end{array}$ & $\begin{array}{l}0.03 \\
\text { Ukraine }\end{array}$ & $\begin{array}{l}10.06 \\
\text { Norway }\end{array}$ & 30.5-fold & $\begin{array}{l}\text { Max } 3.0 \\
71.4 \% \\
\end{array}$ \\
\hline $1000.0-2500.0$ & 16 & $\begin{array}{l}\text { a) } 2.22 \\
\text { b) } 11.08\end{array}$ & $\begin{array}{l}0.06 \\
\text { Botswana }\end{array}$ & $\begin{array}{l}10.60 \\
\text { Qatar }\end{array}$ & 176.6-fold & $\begin{array}{l}\operatorname{Max} 4.0 \\
68.8 \% \\
\end{array}$ \\
\hline $2500.0<$ & 4 & $\begin{array}{l}\text { a) } 5.16 \\
\text { b) } 6.14\end{array}$ & $\begin{array}{l}1.13 \\
\text { Croatia }\end{array}$ & $\begin{array}{l}9.57 \\
\text { United } \\
\text { Arab } \\
\text { Emirates }\end{array}$ & 8.5-fold & $\begin{array}{l}\text { Max } 7.0 \\
62.5 \%\end{array}$ \\
\hline
\end{tabular}

* Weighted with population numbers. ** Original specific values without weighting.

Source: Author's calculations from basic data found in the websites of the ICAO Statistical Yearbook and airports.

This group also includes, in addition to the most vulnerable countries in sub-Saharan Africa, some Asian poverty-stricken countries (for example, Afghanistan), emerging countries (for example, Brazil), countries that lose large numbers of potential tourists due to internal conflicts (for example, Iraq), and some post-Soviet states.

On figure 5, a multitude of members agglomerate close to the origin (a barely perceptible field between the values of the ordinate (15.0) and the abscissa (0.20)), that is, in this group the very low air traffic can be clearly associated with few tourists.

The role of tourism in generating traffic to airports is already clear in the group flanked by tourist intensity values from 0.55 to 0.60 . It is the most pronounced in countries farthest from the origin (for example, in Colombia) producing traffic from 0.68 to 1.00 . 


\section{Distribution of relations between airport penetration and tourist penetration by country}

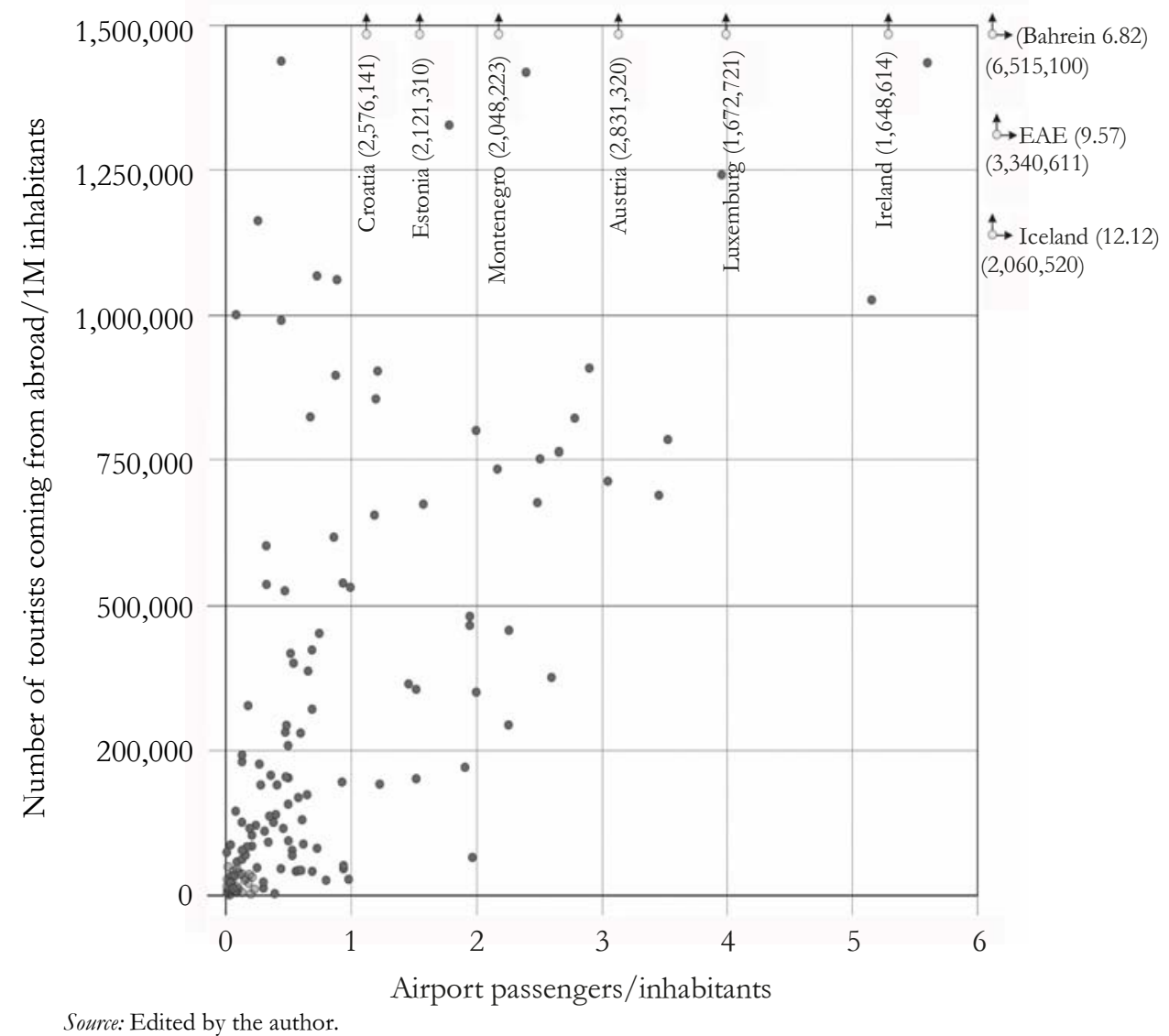

Source: Edited by the author.

b) Weak tourist traffic (50,000 to 250,000 persons/one million inhabitants) is typical of countries forming slightly more than two-thirds of the portfolio consisting of 45 countries and generating less than 0.5 worth of air traffic. In the very high weighted average, which is hundred and fifty times greater than the arithmetic average, the population of many hundreds of millions in the United States, Japan, and Russia plays a decisive role. Among the national extremities, the minimum value is not greater than the minimum value in the previous group (Table 5). The vast majority of the members of this group are concentrated in the zone between the tourism intensity line of 150 thousand tourists $/ 1$ million people and traffic intensity line of 0.7 airports. The overwhelming majority of the $\mathrm{Y}$-axis adjacent members are African, where tourism has only a very modest share in air traffic (because the majority of foreigners arrive on land vehicles from the neighbouring countries).

Regional Statistics, Vol 5, No 2. 2015: 82-107; DOI: 10.15196/RS05205 
Ultimately, (as shown in Figure 5) the increase in air traffic due to tourism is the smallest in the tourism intensity subcategory of 2.5 to 50.0 thousand tourists/1 million inhabitants, which is somewhat stronger in the 50-200 thousand subcategory, and most pronounced in the 200-500 thousand subcategory.

d) The positive impact of tourism generated by foreigners on specific air traffic manifests itself most clearly in the stock of independent countries with a high specific tourist traffic (500-2500 thousand/1 million inhabitants) with values concentrated in a long-drawn-range along the ordinate, which mostly remains below 3.6. The quadrangle stretching up to 1.8 of countries representing minimum values in both dimensions closest to the origin within this portfolio is dominated by post-Soviet and other European former socialist countries. A further block of countries emerges between the specific air traffic indicators of 2.2 to 3.6 with a similar remarkably strong thickening, whose composition is very geographically mixed. Luxembourg, Ireland, Denmark, Switzerland, Spain are displayed with values between 3.6 and 5.6. In this category (0.5-2.5 million tourist / 1 million inhabitants), the impact of tourism on air traffic was already convincing: tourists exceed the local population 9- to 12-fold and generate the greater or by far the largest part of air traffic. However, the fact is that the international transport of the local population has presumably at least the same proportion in the entire air traffic as the visits of foreigners.

\section{Relationship between airport passenger penetration and} tourist penetration by continent

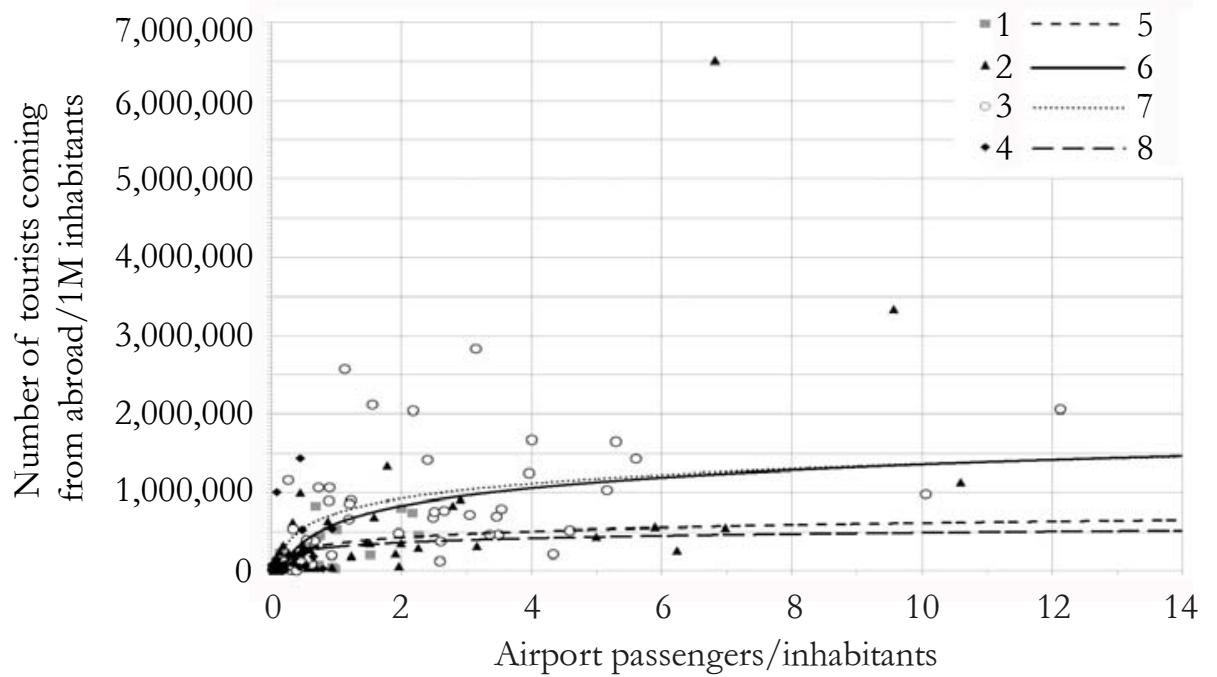

Legend: designation of individual countries: 1 - Latin American, 2 - Asian / Oceanian, 3 - European and North American, 4 - African. Log trend line of R2 concerning 5 - Latin America, 6 - Asia / Oceania, 7 - Europe and North America, 8 - Africa.

Source: Edited by Aron Kovács.

Regional Statistics, Vol 5, No 2. 2015: 82-107; DOI: 10.15196/RS05205 
e) The impact of tourism on air traffic culminates with a mean value of 5.16 in the stock of countries with extremely high tourist traffic $(2.5$ million passengers $/ 1$ million inhabitants). Only Croatia, Austria, Bahrain, and the United Arab Emirates belong to this group (Table 5). Figure 6 shows the distribution relationship between airport passenger penetration and tourist penetration on a logarithmic scale for each continent.

\section{Impact strength of the most important four factors influencing the development of air transport for each continent}

Based on detailed calculations not displayed here, the number of significant correlations does not depend on the number of countries in the given continent, but on natural, demographic, and economic parameters, the quantitative characteristics of the various infrastructures, and on the complex interdependent structure of all of these.

a) The effect of GDP per capita is most strongly manifested in the following - supply with large airports in North and Sub-Saharan Africa,

- airport passenger penetration in 8 large regions (Australia, East and SouthEast Asia, South Asia, Middle East, Eastern Europe, South America, SubSaharan Africa, Western Europe).

b) The effect of tourist penetration is the strongest in the following areas

- supply with large airports in Sub-Saharan and North Africa, the Middle East, and in the zone around the Sahara,

- supply with large airports in the zone around the Sahara and in Sub-Saharan Africa,

- airport passenger penetration in the zone around the Sahara, the Middle East, and Eastern Europe.

c) The effect of population density very significantly prevails in the following areas - airport-density in the Middle East and Central Asia, and

- airport passenger penetration only in South America.

d) The role of road density has a significant level in the following fields

- airport-density in the Middle East, Central Asia, North America, and in the zone around the Sahara,

- in supply with large airports only in the zone around the Sahara,

- in airport passenger penetration exclusively in South America.

Airport passenger penetration stands out with the supply of large airports in Western Europe and an exceptionally strong GDP dependence in Eastern Europe, while in the Middle East as well as in Central Asia, a strong relation exists with airport and population density. In East and South-East Asia, and in Australia, the relationship between airport density and motorway density stands out, while in North Africa the correlation between airport density and tourist penetration is significant, mainly owing to tourist traffic of tens of millions in Egypt, Tunisia, and Morocco.

Regional Statistics, Vol 5, No 2. 2015: 82-107; DOI: 10.15196/RS05205 
Due to the extremely harsh natural conditions in the dry zone around the Sahara, one of the main criteria for airport-construction is road accessibility, which is quite poor in that region. The relationship between large airport-supply and airport density is even closer. The huge region of sub-Saharan Africa, which is more or less rainy, therefore predominantly engaged in plantation farming and has a significant extractive industry, is mainly characterized by the fact that GDP plays a big role in the supply with large airports, while the airport passenger penetration primarily depends on the supply with large airports. (That is, airports with smaller runways play a much smaller role in air traffic than assumed.) In Central America, passenger traffic is primarily generated by foreign tourists. In South America, passenger intensity is almost equally dependent on the population and road density as well as on GDP.

\section{Research findings}

Based on the geographical logic and our past experiences (limited to only a few countries), we examined the potential impact of 8 economic/infrastructural and social factors selected to our working hypothesis on the three main characteristics of aviation. a) Worldwide. Compared with our hypothesis, neither the area as well as the population and road density of the particular country nor the figures of GDP per capita and tourist penetration did not affect the density of the entire airport portfolio (Moreover, the relationship with internet use, which is irrelevant in terms of our topic, was also insignificant).

The calculations confirmed the significant correlations assumed between the indicator of large airports per unit of population and GDP as well as passenger penetration, but the relationship with tourist penetration was already weak. On the other hand, (in contrast with our hypothesis), the relationship was especially significant between passenger penetration and the supply with large airports. (Among the other, not very relevant indicators, there was a significant relationship only with car supply and internet use, but not with transport infrastructures.)

In addition to the GDP, airport passenger penetration (number of passengers and of the population) has a highly significant relationship with the supply of large airports (and significantly correlate with the automobile supply), but the impact of tourist penetration is rather weak in this respect.

b) The number of significant correlations of individual continents is independent of the number of countries. We did not formulate preliminary hypotheses on the correlation of aviation indicators of continents, but as a result of the calculations, it became clear that in North America tourism (by reason of its significant economic role played in several countries) population density in Central Asia and road density in Australia show a highly significant relationship, while GDP is among the major impact factors both in underdeveloped and developed regions. 


\section{REFERENCES}

PWC (2014): Connectivity and growth Directions of travel for airport https://www.pwc.com/gx/en/capital-projects-infrastructure/publications/ assets/pwc-connectivity-growth.pdf (downloaded: Dec 2015).

BUTTON, K. - TAYLOR, S. (2000): International air transportation and economic development Journal of Air Transport Management 6 (4): 209-222.

ATAG (2012): Aviation (Benefits beyond Borders) https://www.oxfordeconomics.com/publication/download/239338 (downloaded: Dec 2015).

ERDŐSI, F. (1998): A légi këzlekedés általános és regionális földrajza, légiközlekedés-politika Első kötet. MALÉV Rt., Budapest.

ERDŐSI, F. (1999): Légi közlekedés és területi fejlődés Tér és Társadalom 13 (4): 45-76.

Erdősi, F. (2000): A kommunikáció (közlekedés-távközlés) szerepe a terület-és településfejlódésben Első kötet. VÁTI, Budapest.

ERDŐSI, F. (2003): Múholdas vagy fénykábeles hálózatok Hiradástechnika 59 (9): 43-50.

ERDŐsI, F. (2003a): A világ légi közlekedésének főbb tendenciái Közlekedéstudományi Szemle 53 (2): 54-59.

ERDősI, F. (2010): Közlekedésföldrajz In: Tóth J. (szerk.): Világföldrajz pp. 513-596., Akadémiai Kiadó, Budapest.

Erdősi, F. (2010a): A távközlés és infokommunikáció földrajza. In: Tóth J. (szerk.): Világoöldrajz pp. 483-512. Akadémiai Kiadó, Budapest.

ERDŐSI, F. (2015): A hárompólusú Közel-Kelet közlekedése Kézirat, MTA KRTK, Pécs.

KÖZLEKEDÉsI És VÍZÜGYI MINISZTÉRIUM (KVM) (2001): Fehér Könyv. Európai közlekedéspolitika 2010-ig: Itt ą idö dönteni Budapest.

AIRBUS S.A.S. (2013): Future Journeys 2013-2032. Global Market Forecast https:/ /www.airbusgroup.com (downloaded: Dec 2015).

HANSMAN, R. J. (2005): The impact of information technologies on air transportation In: AIAA Aerospace Sciences Conference pp. 1-12., AIAA January 2005, Reno.

Airport Authority Hong KONG (AAHK) (2010): HKIA Master Plan 2030 Technical Report. Chapter 2: Air Traffic Demand Forecast

http://www.threerunwaysystem.com/en/Information/Airport_master_plan_20 30.aspx (downloaded: Dec 2015).

Owram, K. (2015): How Iceland's airlines have helped Spur a tourism boom Financial Post http://business.financialpost.com/news/transportation/how-icelands-airlineshave-helped-spur-a-tourism-boom-lifting-its-battered-economy-back-to-health (downloaded: Dec 2015).

ICAO (2014): Statistical Yearbook 2013 ICAO, Canada.

IsHutkina, M. A. - HANSMAN, R. J. (2009): Analysis of Interaction between Air Transportation and Economic Activity Report. No. ICAT 2009-2, March, Cambridge, MA 02139 USA. http://dspace.mit.edu/bitstream/handle/1721.1/44957/Ishutkina_ICAT-20092.pdf?sequence $=1$ (downloaded: Dec 2015).

Morphet, H. - BotTini, C. (2013): Propensity to fly in emerging economies: Implications for infrastructure investment https://www.pwc.com/en_GX/gx/capital-projectsinfrastructure/pdf/the_new_normal_for_airport_investment__06_propensity_to_fly.pdf (downloaded: Dec 2015).

CIA (2015): The World Factbook https://www.cia.gov/library/publications/the-worldfactbook/index.html

Regional Statistics, Vol 5, No 2. 2015: 82-107; DOI: 10.15196/RS05205 